\title{
SPG4 Founder Effect in French Canadians with Hereditary Spastic Paraplegia
}

\author{
Inge. A. Meijer, Nicolas Dupré, Bernard Brais, Patrick Cossette, Judith St-Onge, \\ Marie-France Rioux, Melanie Benard, Guy A. Rouleau
}

\begin{abstract}
Background: The most common cause of autosomal dominant Hereditary Spastic Paraplegia (HSP) is mutations in the SPG4 gene. We have previously identified novel SPG4 mutations in a collection of North American families including the c.G1801A mutation present in two families from Quebec. The aim of this study is to estimate the frequency of the c.G1801A mutation in the French Canadian (FC) population and to determine whether this mutation originates from a common ancestor. Methods: We collected and sequenced exon 15 in probands of 37 families. Genotypes of markers flanking the SPG4 gene were used to construct haplotypes in five families. Clinical information was reviewed by a neurologist with expertise in HSP. Results: We have identified three additional unrelated families with the c.G1801A mutation and haplotype analysis revealed that all five families share a common ancestor. The mutation is present in $7 \%$ of all our FC families and explains half of our spastin linked FC families. The phenotype associated with the c.G1801A genotype is pure HSP with bladder involvement. Conclusion: In this study we have determined that the relative frequency of the c.G1801A mutation in our FC collection is 7\%, and approximately 50\% in the spastin positive FC group. This mutation is the most common HSP mutation identified in this population to date and is suggestive of a founder effect in Quebec.
\end{abstract}

RÉSUMÉ: Effet fondateur du gène SPG4 chez les Canadiens-français atteints de paraplégie spastique héréditaire. Contexte : La cause la plus fréquente de la paraplégie spastique héréditaire (PSH) dominante autosomique est une mutation du gène SPG4. Nous avons déjà identifié de nouvelles mutations du gène SPG4 dans un groupe de familles nord-américaines, dont la mutation c.G1801A qui est présente chez 2 familles du Québec. Le but de cette étude était d'estimer la fréquence de la mutation c.G1801A dans la population canadienne-française (CF) et de déterminer si cette mutation provient d'un ancêtre commun. Méthodes : Nous avons recueilli et séquencé l'exon 15 de chacun des cas index des 37 familles. Le génotypage de marqueurs adjacents au gène SPG4 a été utilisé pour construire des haplotypes dans 5 familles. Les données cliniques ont été révisées par un neurologue ayant une expertise dans le domaine de la PSH. Résultats : Nous avons identifié 3 autres familles non apparentées qui ont la mutation c.G1801A et l'analyse des haplotypes a montré que ces 5 familles ont un ancêtre commun. La mutation est présente chez $7 \%$ de nos familles CF et explique la maladie liée à la spastine chez la moitié de nos familles CF. Le phénotype associé au génotype cG1801A est une PSH pure avec atteinte vésicale. Conclusion: Nous avons établi que la fréquence relative de la mutation cG1801A chez nos cas CF est de 7\% et de 50\% dans le groupe de cas CF positifs pour la spastine. C'est la mutation la plus fréquente dans le gène de la PSH qui ait été identifiée dans cette population jusqu'à maintenant et nos données sont compatibles avec la présence d'un effet fondateur au Québec.

Can. J. Neurol. Sci. 2007; 34: 211-214

The Hereditary Spastic Paraplegias are a clinically and genetically heterogeneous group of neurodegenerative disorders characterized by progressive lower limb spasticity and weakness. ${ }^{1}$ Hereditary Spastic Paraplegias are clinically grouped as pure or complicated HSP. The complicated form of HSP includes patients with lower limb spasticity and additional neurological features such as optic neuropathy, dementia, ataxia, deafness, mental retardation, or extrapyramidal disturbance. ${ }^{1,2}$ The genetic heterogeneity in HSP is demonstrated by the large number of loci mapped for the disease (SPG1 through SPG 31). . $^{3-}$ ${ }^{7}$ Identification of eleven HSP genes has revealed that several pathophysiological pathways are involved in this disease including impaired axonal transport, a common link with other neurodegenerative diseases. $3,8,9$
The most common cause of HSP is mutations in the SPG4 gene, explaining $40 \%$ of all autosomal dominant HSP cases. ${ }^{10,11}$ Recently, Depienne and colleagues ${ }^{12}$ also reported SPG4 mutations in $12 \%$ of apparently sporadic HSP cases. The SPG4

From the Center for the Study of Brain Diseases (IAM, ND, BB, PC, SOJ, MB, GAR), CHUM Research Center, Notre-Dame Hospital: Biology Department (IAM), McGill University; Faculty of Medicine (ND), Laval University, Department of Neurological Sciences, CHAUQ - Enfant-Jésus, Montreal; Service de neurologie (MFR), Centre hospitalier de l'Université de Sherbrooke, Sherbrooke, QC, Canada.

Received July 11, 2006. AcCePted in finAl form December 4, 2006.

Reprint requests to: Guy A. Rouleau, Center for the Study of Brain Diseases, CHUM Research Center - Notre-Dame Hospital, J.A. de Seve Pavillon, Room Y-3633, 1560, Sherbrooke Street East, Montreal, Quebec, H2L 4M1, Canada. 


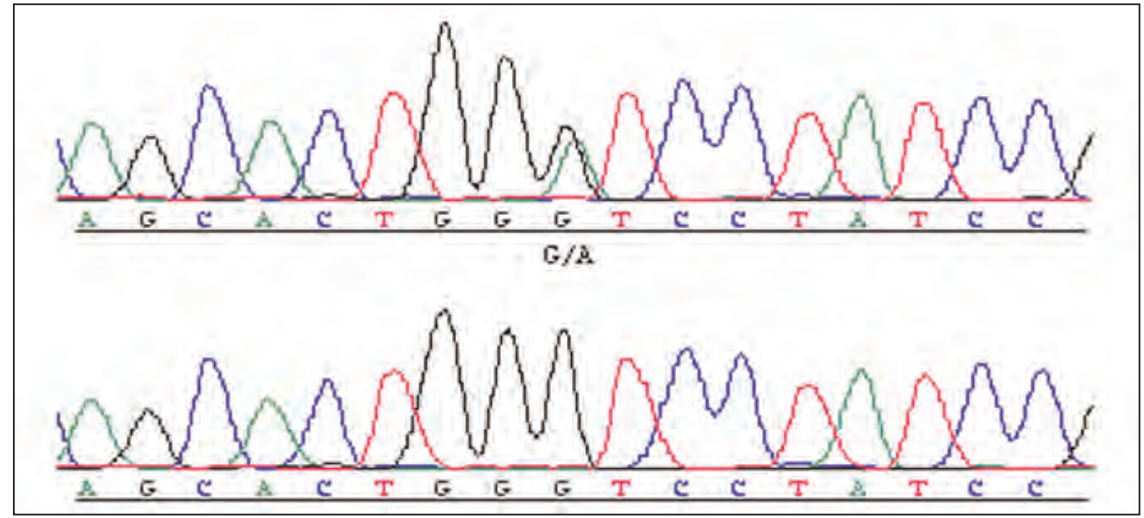

Figure: Sequence analysis. The sequence trace of patient DNA carrying the c.G1801A heterozygous mutation compared to a control sample. This mutation leads to a p.G559D missense change in the AAA cassette.

gene encodes spastin, which has been implicated in various processes such as endosomal trafficking and cytoskeletal rearrangement, but the most studied function is microtubule severing ${ }^{13}$ through its MIT (microtubule-interacting and trafficking molecules) domain ${ }^{14}$ and the AAA (ATPase associated with various cellular activities) domain. Since the cloning of the SPG4 gene, ${ }^{15}$ over 150 mutations have been reported across the gene. ${ }^{16-18}$ The majority of missense mutations occur in the AAA cassette including the c.G1801A mutation we previously reported in two French Canadian (FC) families. ${ }^{19,20}$

In this study we determine the relative frequency of the c.G1801A mutation in our French Canadian collection, we provide evidence that the subjects carrying this mutation originate from a common ancestor, and we describe the associated phenotypic features.

\section{MeTHODS}

\section{Subjects}

Subjects gave written informed consent to participate in our study, which was approved by the local ethics review board (Centre Hospitalier de l'Université de Montréal). Peripheral blood samples were obtained from 37 probands and DNA was extracted by standard methods. Probands were recruited through their treating neurologist, who had performed a complete neurological examination, spinal magnetic resonance imaging, and basic blood tests. Their chart was thereafter reviewed by a neurologist (ND) with expertise in HSP. French Canadian ancestry was determined by establishing that parents and grandparents of the probands were of FC descent.

\section{Genotyping}

Polymorphic markers were amplified by PCR incorporating radiolabeled $S^{35}$ dATP into the product. The products were separated on $6 \%$ denaturing polyacrylamide gels and visualized on autoradiographic film. The following markers were genotyped in and around the SPG4 gene: D2S2201, D2S1383, D2S352, D2S2347, D2S367, D2S1325, and D2S2328. Haplotype construction assuming minimal recombination was performed manually and ordered according to the goldenpath physical map (http://www.genome.ucsc.edu/).

\section{Mutation Detection}

Exon 15 was amplified using flanking primers previously reported by Meijer et al $2001^{20}$ and PCR products were sequenced at the McGill University and Genome Quebec Centre for Innovation.

\section{RESULTS}

We have previously identified spastin mutations in 15 North American families including 8 novel mutations and 2 recurring mutations in Caucasian families. ${ }^{20}$ The c.G1801A mutation was detected in 2 out of $32 \mathrm{FC}$ probands, which was suggestive of a common FC mutation. In the present study we have collected and sequenced another 37 families for this mutation in exon 15 . We identified three additional families with the common c.G1801A mutation (Figure). The c.G1801A mutation therefore has a 7\% frequency (5/69) in our FC sample. This also represents approximately half of the spastin mutations found in the FC cohort. To determine whether the families share the mutation because of a genetic link or because of a mutational hotspot, we performed haplotype analysis around the SPG4 locus (Table 1). The haplotype analysis indicates that all five families share a segment of at least $4 \mathrm{Mb}$ and thus originate from a common ancestor. Unfortunately, insufficient archival data did not permit genealogical studies for these five families.

The phenotype associated with this mutation is that of pure HSP with or without bladder involvement (Table 2). The age of onset varies greatly between families and mild sensory symptoms are only seen in two probands. For subject R19935, detailed clinical information was not available, but this patient was diagnosed with pure adult onset HSP by the treating neurologist, and had a family history of pure HSP.

\section{Discussion}

We have identified the first common spastin mutation in Quebec, which is suggestive of a founder effect. This c.G1801A mutation has not been reported by other groups and seems to be specific to the FC population. Our laboratory has the largest collection of FC HSP cases and the c.G1801A mutation is the only recurring HSP mutation in this population, with a frequency of $7 \%$. The other genetic causes for HSP in Quebec include 
Table 1: Haplotype analysis around the SPG4 locus

\begin{tabular}{|c|c|c|c|c|c|c|c|}
\hline Marker & Location Mb & X2754 & R9259 & R12045 & R13395 & R19537 & CEPH freq \\
\hline D2S2201 & 21 & 2 & 2 & 4 & 2 & 2 & \\
\hline D2S2383 & 29 & 11 & 2 & 11 & 11 & 11 & \\
\hline D2S352 & 31 & 5 & 5 & 5 & 5 & 5 & 0,125 \\
\hline$S P G 4 X 15$ & 32 & A & A & A & A & A & $\mathrm{n} / \mathrm{a}$ \\
\hline D2S2347 & 33 & 4 & 4 & 4 & 4 & 4 & 0,054 \\
\hline D2S367 & 34 & 8 & 8 & 8 & 8 & 8 & 0,250 \\
\hline D2S1325 & 35 & 2 & 2 & 2 & 2 & 2 & 0,310 \\
\hline D2S2328 & 40 & 10 & 5 & 5 & 5 & 12 & \\
\hline
\end{tabular}

* n/a: not available

mutations in: PLP (1 family), atlastin (1 family), spastin (6 families/6 mutations) and SPG27 (1 family), but they all occur at a much lower frequency ${ }^{20,21}$ (personal communication).

Interestingly, the frequency of spastin mutations in our French-Canadian collection is lower than the $40 \%$ that is usually reported. ${ }^{15}$ Several other groups have reported lower spastin frequencies in their cohorts for example $19 \%,{ }^{22} 22 \%,{ }^{23}$ and $17 \% .{ }^{24} \mathrm{~A}$ possible explanation for this discrepancy is that all these studies did not select for spastin linked families. Alternatively, given the French Canadian founder effect, spastin mutations may simply have been introduced at a lower frequency in the founders. In addition, our cohort might include more sporadic cases which have a lower spastin mutation rate, ${ }^{12}$ or there is a higher number of micro-deletions in our samples which we could not detect with the available methods. ${ }^{25}$

Founder mutations have previously been studied in French Canada because of historical roots of the populations and many genes have been identified for these mostly recessive diseases such as Autosomal Recessive Spastic Ataxia of CharlevoixSaguenay and Hereditary Motor and Sensory neuropathy with Agenesis of the Corpus Callosum. ${ }^{26,27}$ The c.G1801A mutation is one of the few examples of a common ancestor in Quebec for a dominant disease. Another example is Clouston hidrotic ectodermal dyspasia, where a $1.3 \mathrm{cM}$ common haplotype was found in French-Canadian families. ${ }^{28}$ The only other reported founder mutation in spastin was reported by Orlacchio et al. ${ }^{29}$ The p.N386S change was detected in 9/15 Scottish families and those families shared a $\sim 9 \mathrm{Mb}$ haplotype. Recently, Namekawa and colleagues ${ }^{30}$ also showed evidence of a common ancestor for the R495W atlastin mutation in the French population.

The phenotype associated with SPG4 mutations is very variable and mutation carriers can present with pure HSP, ataxia, ${ }^{31}$ Primary Lateral Sclerosis (PLS), early onset Amyotrophic Lateral Sclerosis (ALS), ${ }^{32}$ or dyplastic corpus callosum. ${ }^{33}$ The probands with the c.G1801A mutation present with a pure form of HSP and the disease is uniform in all five families. In addition, the penetrance associated with this mutation is likely complete since all identified mutation carriers have HSP. Even though the FC HSP population is genetically diverse, it is advisable to screen for the c.G1801A mutation as a priority in patients with dominant or sporadic adult onset HSP to improve efficiency of genetic testing. Interestingly, successful prenatal diagnosis for spastin mutations has been reported and offers an option for families with severe early onset HSP. ${ }^{34}$

Table 2: Clinical features of probands with the c.G1801A mutation*

\begin{tabular}{|c|c|c|c|c|}
\hline Subjects & X2754 & R9259 & R12045 & R13395 \\
\hline Family History & + & + & + & + \\
\hline Age of onset & 12 & 25 & 70 & 35 \\
\hline Age of evaluation & 25 & 40 & 77 & 38 \\
\hline Hyperreflexia in the arms & + & - & - & + \\
\hline Hyperreflexia in the legs & + & + & + & + \\
\hline Leg spasticity & - & + & + & + \\
\hline Urinary symptoms & - & + & + & - \\
\hline Vibration at the toes & normal & normal & deceased & deceased \\
\hline plantar responses & indifferent & extensor & extensor & extensor \\
\hline MRI results & $\begin{array}{l}\text { Total spine } \\
\text { normal }\end{array}$ & $\begin{array}{l}\text { Total spine } \\
\text { normal }\end{array}$ & $\begin{array}{c}\text { not } \\
\text { available }\end{array}$ & $\begin{array}{c}\text { Total spine } \\
\text { and brain normal }\end{array}$ \\
\hline
\end{tabular}

* Subject R19935 is not represented since insufficient clinical information was provided. 
A recent report showed that in a Drosophila model of spastin with adult onset neurodegeneration, the phenotype was partially alleviated by treatment with vinblastine, a modulator of microtubule stability. ${ }^{35}$ These findings offer hope for the development of a treatment for spastin related HSP and further underlines the importance of testing for spastin mutations.

\section{ACKNOWLEDGEMENTS}

The authors thank the families for their participation in this study as well as Melanie Benard and Isabelle Thibault for patient recruitment. GAR, PC and ND are supported by the Canadian Institutes for Health Research (CIHR). BB is a scholar of the Fonds de la Recherche en Sante du Quebec (FRSQ).

\section{Electronic Sources}

UCSC Human Genome Project Working Draft (Golden Path), http://genome.ucsc.edu/

\section{REFERENCES}

1. Harding AE. Hereditary spastic paraplegias. [Review]. Semin Neurol. 1993;13:333-6.

2. Reid E. Science in motion: common molecular pathological themes emerge in the hereditary spastic paraplegias. J Med Genet. 2003;40:81-6.

3. Fink JK. Advances in the hereditary spastic paraplegias. Exp Neurol. 2003;184 Suppl 1:S106-10.

4. Simpson MA, Cross H, Proukakis C, Pryde A, Hershberger R, Chatonnet A, et al. Maspardin is mutated in mast syndrome, a complicated form of hereditary spastic paraplegia associated with dementia. Am J Hum Genet. 2003;73:1147-56.

5. Hodgkinson CA, Bohlega S, Abu-Amero SN, Cupler E, Kambouris $\mathrm{M}$, Meyer BF, et al. A novel form of autosomal recessive pure hereditary spastic paraplegia maps to chromosome $13 \mathrm{q} 14$. Neurology. 2002;59:1905-9.

6. Klebe S, Azzedine H, Durr A, Bastien P, Bouslam N, Elleuch N, et al. Autosomal recessive spastic paraplegia (SPG30) with mild ataxia and sensory neuropathy maps to chromosome $2 \mathrm{q} 37.3$. Brain. 2006; Jun 129(Pt 6):1456-6.

7. Zuchner S, Kail ME, Nance MA, Gaskell PC, Svenson IK, Marchuk DA, et al. A new locus for dominant hereditary spastic paraplegia maps to chromosome 2p12. Neurogenetics. 2006;7:127-9.

8. Crosby $\mathrm{AH}$, Proukakis $\mathrm{C}$. Is the transportation highway the right road for hereditary spastic paraplegia? Am J Hum Genet. 2002;71:1009-16.

9. Rainier S, Chai JH, Tokarz D, Nicholls RD, Fink JK. NIPA1 gene mutations cause autosomal dominant hereditary spastic paraplegia (SPG6). Am J Hum Genet. 2003;73:967-71.

10. Durr A, Davoine CS, Paternotte C, von Fellenberg J, Cogilinicean $\mathrm{S}$, Coutinho $\mathrm{P}$ et al. Phenotype of autosomal dominant spastic paraplegia linked to chromosome 2. Brain. 1996;119 (Pt 5): 1487-96.

11. Soderblom C, Blackstone C. Traffic accidents: molecular genetic insights into the pathogenesis of the hereditary spastic paraplegias. Pharmacol Ther. 2006;109:42-56.

12. Depienne C, Tallaksen C, Lephay JY, Bricka B, Poea-Guyon S, Fontaine B, et al. Spastin mutations are frequent in sporadic spastic paraparesis and their spectrum is different from that observed in familial cases. J Med Genet. 2006;43:259-65.

13. Errico A, Ballabio A, Rugarli E. Spastin, the protein mutated in autosomal dominant hereditary spastic paraplegia, is involved in microtubule dynamics. Hum Mol Genet. 2002;15:153-63.

14. Roll-Mecak A, Vale RD. The Drosophila homologue of the hereditary spastic paraplegia protein, spastin, severs and disassembles microtubules. Curr Biol. 2005;15:650-5.

15. Hazan J, Fonknechten N, Mavel D, Paternotte C, Samson D, Artiguenave F, et al. Spastin, a new AAA protein, is altered in the most frequent form of autosomal dominant spastic paraplegia. Nat Genet. 1999;23:296-303.
16. Hentati A, Deng HX, Zhai H, Chen W, Yang Y, Hung WY et al. Novel mutations in spastin gene and absence of correlation with age at onset of symptoms. Neurology. 2000;55:1388-90.

17. Burger J, Fonknechten N, Hoeltzenbein M, Neumann L, Bratanoff E, Hazan J, et al. Hereditary spastic paraplegia caused by mutations in the SPG4 gene. Eur J Hum Genet. 2000;8:771-6.

18. Fonknechten N, Mavel D, Byrne P, Davoine CS, Cruaud C, Bonsch $\mathrm{D}$, et al. Spectrum of SPG4 mutations in autosomal dominant spastic paraplegia. Hum Mol Genet. 2000;9:637-44.

19. Yip AG, Durr A, Marchuk DA, Ashley-Koch A, Hentati A, Rubinsztein DC, et al. Meta-analysis of age at onset in spastinassociated hereditary spastic paraplegia provides no evidence for a correlation with mutational class. J Med Genet. 2003;40:e106.

20. Meijer I, Hand C, Cossette P, Figlewicz D, Rouleau G. Spectrum of SPG4 mutations in a large collection of North American families with hereditary spastic paraplegia. Arch Neurol. 2002;59:281-6.

21. Meijer IA, Cossette P, Roussel J, Benard M, Toupin S, Rouleau GA. A novel locus for pure recessive hereditary spastic paraplegia maps to 10q22.1-10q24.1. Ann Neurol. 2004;56:579-82.

22. McDermott CJ, Burness CE, Kirby J, Cox LE, Rao DG, Hewamadduma $\mathrm{C}$, et al. Clinical features of hereditary spastic paraplegia due to spastin mutation. Neurology. 2006;67:45-51.

23. Crippa F, Panzeri C, Martinuzzi A, Arnoldi A, Redaelli F, Tonelli A, et al. Eight novel mutations in SPG4 in a large sample of patients with hereditary spastic paraplegia. Arch Neurol. 2006;63:750-5.

24. Sauter S, Miterski B, Klimpe S, Bonsch D, Schols L, Visbeck A, et al. Mutation analysis of the spastin gene (SPG4) in patients in Germany with autosomal dominant hereditary spastic paraplegia. Hum Mutat. 2002;20:127-32.

25. Depienne C, Fedirko E, Forlani S, Cazeneuve C, Ribai P, Feki I, et al. Exon deletions of SPG4 are a frequent cause of hereditary spastic paraplegia. J Med Genet. 2006;43:259-65.

26. Laberge AM, Michaud J, Richter A, Lemyre E, Lambert M, Brais $\mathrm{B}$, et al. Population history and its impact on medical genetics in Quebec. Clin Genet. 2005;68:287-301.

27. Dupre N, Bouchard J-P, Brais B, Rouleau GA. Hereditary ataxia, spastic paraparesis and neuropathy in the French-Canadian population. Can J Neurol Sci. 2006;33:149-57.

28. Kibar Z, Dube MP, Powell J, McCuaig C, Hayflick SJ, Zonana J, et al. Clouston hidrotic ectodermal dysplasia (HED): genetic homogeneity, presence of a founder effect in the French Canadian population and fine genetic mapping. Eur J Hum Genet. 2000;8:372-80.

29. Orlacchio A, Kawarai T, Totaro A, Errico A, St George-Hyslop PH, Rugarli EI, et al. Hereditary spastic paraplegia: clinical genetic study of 15 families. Arch Neurol. 2004;61:849-55.

30. Namekawa M, Nelson I, Ribai P, Durr A, Denis E, Stevanin G, et al. A founder effect and mutational hot spots may contribute to the most frequent mutations in the SPG3A gene. Neurogenetics. 2006;7:131-2.

31. Nielsen JE, Johnsen B, Koefoed P, Scheuer KH, Gronbech-Jensen M, Law I, et al. Hereditary spastic paraplegia with cerebellar ataxia: a complex phenotype associated with a new SPG4 gene mutation. Eur J Neurol. 2004;11:817-24.

32. Meyer T, Schwan A, Dullinger JS, Brocke J, Hoffmann KT, Nolte $\mathrm{CH}$, et al. Early-onset ALS with long-term survival associated with spastin gene mutation. Neurology. 2005;65:141-3.

33. Alber B, Pernauer M, Schwan A, Rothmund G, Hoffmann KT, Brummer D, et al. Spastin related hereditary spastic paraplegia with dysplastic corpus callosum. J Neurol Sci. 2005;236:9-12.

34. Nielsen JE, Koefoed P, Kjaergaard S, Jensen LN, Norremolle A, Hasholt L. Prenatal diagnosis of autosomal dominant hereditary spastic paraplegia (SPG4) using direct mutation detection. Prenat Diagn. 2004;24:363-6.

35. Orso G, Martinuzzi A, Rossetto MG, Sartori E, Feany M, Daga A. Disease-related phenotypes in a Drosophila model of hereditary spastic paraplegia are ameliorated by treatment with vinblastine. J Clin Invest. 2005;115:3026-34. 